\title{
イオン液体のユニークな熱物性
}

西 川 恵子*1

\section{Unique Thermal Behaviors of Ionic Liquids}

\author{
Keiko NISHIKAWA*1 \\ ${ }^{* 1}$ Graduate School of Advanced Integration Science, Chiba University, 1-33 Yayoi-cho, Inage-ku, Chiba-shi, Chiba 263-8522, Japan
}

(Received May 22, 2012, Accepted August 6, 2012)

\begin{abstract}
Room-temperature ionic liquids (RTILs) constitute a new class of liquids that attract much attention because of their characteristic properties and potential utilities as functional liquids. Unique properties are remarkably manifested in their thermal behaviors such as low melting point despite being salts, hardness in crystallization, premelting over a wide temperature range, excessive supercooling, and the existence of complex thermal histories. In addition, we found peculiar thermal behaviours at the phase changes of imidazoliumbased RTILs, namely 'rhythmic melting and crystallization', 'intermittent crystallization' in the premelting regions and ultraslow phase changes. These unique thermal behaviours of imidazolium-based RTILs are attributed to conformational changes and flexibility of alkyl chains bonding to the imidazolium ring.
\end{abstract}

\section{1. はじめに}

イオン液体とは，イオンのみから構成されているにもかか わらず，室温付近で液体状態の物質群の総称である．高い熱 安定性, 難燃性, 両親媒性, 高いイオン伝導度, 広い電気 空, 極めて低い蒸気压 ${ }^{11}$ 等で特徵づけられる. 構成イオンの 多くは有機イオンや錯イオンであるため, イオンをデザイン することにより物性の調節や新規機能付与が可能であり, デ ザイナー液体ともよばれている，このように，イオン液体 は, 『新規な物質』と呼ぶにふさわしい様々な特異な性質を 有している. その特異性は, 熱物性のユニークさとして現れ ることが多い. 本記事では, 相挙動に焦点を当てた熱現象を 中心にイオン液体の特異性のいくつかを紹介する. 本記事で 『イオン液体』と記した場合, 液体状態を指すのではなく, 前述した物質群を指し, 結晶状態やガラス状態も包含させて いるとご了解いただきたい。

多くのイオン液体において, 数 $10 \sim 100 \mathrm{~K}$ にわたる過冷 却状態が存在し, $10 \mathrm{~K}$ 以上の温度領域にわたる前駆融解現 象, 非平衡状態を暗示するようなゆっくりとした構造緩和現 象などが観測される. また, 熱履歴によって熱挙動は様々に 変化する.このような特異的な現象が起こる原因の一つは, 構成イオンの立体配座の多様性と複数の配座間を比較的容易 に行き来できるフレキシビリティである，イオン液体の相変 化は, 立体配座の変化とリンクしている場合がほとんどであ る.これらが, 複雑な相挙動を引き起こす。 また, 立体配座 の変化に時間がかかる場合には, 信じがたいような長い時間 を要する相変化 ${ }^{2)}$ の因となっている.

イオン液体の熱物性に関して, これまでも多くの研究結果 が報告され，有用な情報が得られてきた。しかし，中には， 研究者あるいは実験条件が異なると全く異なる結果が報告さ

*1 千葉大学大学院融合科学研究科ナノサイエンス専攻（干2638522 千葉市稲毛区弥生町 1-33)

†1無視できる程度の非常に低い蒸気圧 ${ }^{1)}$ であることは，イオン液 体を試料とした『真空の液体科学』が展開できることを意味 する.
れており，大きな混乱を招いていることも事実である. 例え ば, 最も基本的な熱力学量である融点の報告が $10 \mathrm{~K}$ 以上違 いがある例が多数存在する。これらの混乱の原因の一つは, 試料の純度が問題である. いま一つは, 相転移や構造緩和に 非常に長い時間を要するイオン液体も存在するためである. 相転移あるいは緩和の時間より速い速度で加熱や冷却を行っ た熱測定結果では，とんでもないデータとなる.

イオン液体の相挙動を示差熱分析（DSC）などで実験し た報告では，熱の出入りのピークを不用意に『相転移』とし ているものもあるが，注意が必要である。相転移は, Fig. 1 (a)に示されるように, 温度に対する Gibbs energy 変化曲線 を二つの相 $\left(\mathrm{Ph}_{\mathrm{L}}\right.$ と $\left.\mathrm{Ph}_{\mathrm{H}}\right)$ について描いた場合, その交点で 定義される相転移点 $\left(T_{\mathrm{t}}\right)$ で, Gibbs energy の低い相間で の乗り換え現象である。それに対して,『構造緩和』は,

Fig. 1(b)に示されるように, 二つの状態間で Gibbs energy の高い状態 $\left(\mathrm{Ph}_{1}\right)$ から低い状態 $\left(\mathrm{Ph}_{2}\right)$ への変化である. 本記事では，明確に前者の場合は『相転移』と記すが，多く の場合, 『構造緩和』を含めてより広い意味で『相変化』あ るいは『相挙動』と記す.

複雑なイオン液体の相挙動を解明するためには, 注意深い 実験が必要である. 相挙動の研究には, DSCが最も一般的 な手法である.イオン液体の相挙動研究のための DSC に必 要な要件は, 感度および精度が良いこと, 降温・昇温の切り 替えが自在にできること, 非常にゆっくりした掃引速度での

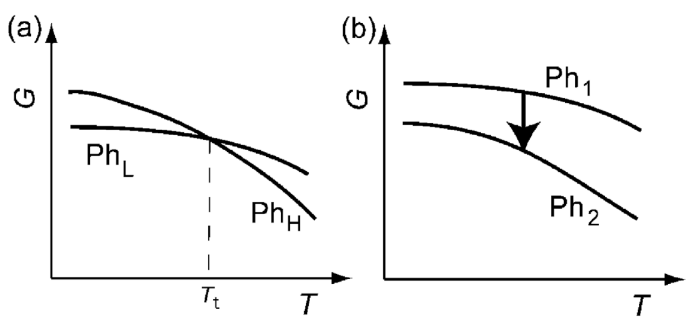

Fig. 1 Gibbs energy vs. temperature. (a) Phase transition. (b) Structure relaxation. 
実験が可能であること等が挙げられる。このような, イオン 液体の相挙動観測に最適の超高感度 DSC 装置については, 原著論文を参照願いたい3)。 また，何らかの熱の出入りが有 る場合，熱分析実験は，非常に感度良く熱現象の存在を教え てくれる．しかし，熱分析だけからは何が起こっているかが 分からない，熱現象の詳細を解明するためには，他手法との 同時測定や，同じ条件下で他の測定を行い結果の突き合わせ が必要となる．このために，Raman 散乱で構造の変化を同 時に検知できる熱分析装置が開発された4)。 また，イオン液 体の相挙動の時間スケールが，NMRの得意とする時間領域 となっているため, 相変化に伴うダイナミクスの解明も注目 されている2,5-8).

本記事では, 最も信頼の㧍けるデータが多く, また相挙動 の詳細が報告されているイミダゾリウムカチオン (1-Alkyl3-methylimidazolium cation, 以下 $\left[\mathrm{C}_{\mathrm{n}} \mathrm{mim}\right]^{+}$と省略する) を含むイオン液体の相挙動について, 我々の研究結果を中心 に報告する，我々の用いている熱分析装置の一つである手作

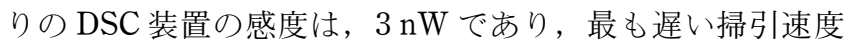
は $0.01 \mathrm{mK} / \mathrm{s} （ 1 \mathrm{~K}$ の温度変化に 28 時間）である ${ }^{3)}$.これに 対して, 市販されている通常の DSC 装置の感度は $3 \sim 5 \mu \mathrm{W}$ 程度である. 今回報告する結果のいくつかは，市販の装置よ り $10^{3}$ 倍の感度と非常にゆっくりした掃引速度で初めて可能 になったと言える。また，本記事で紹介する試料の相挙動 が，イオン液体の相挙動の特徵のほとんどを備えていること を打断りしておく。

\section{2. 立体配座変化と連動した相変化}

イオン液体の構成イオンには, 複数個の安定立体配座が存 在することが多くの実験で明らかにされている，著者の知る 限りでは, イオン液体における多様な立体配座の重要性を最 初に指摘したのは, Holbrey グループ9) と濱ログループ10,11 である。それぞれ独立に $\left[\mathrm{C}_{4} \mathrm{mim}\right] \mathrm{Cl}$ に結晶多形が存在し， 結晶構造解析の結果，イミダゾリウム環についたブチル基の 立体配座の違いにより異なる結晶ができることを明らかにし た。 また, Holbrey 等は, 立体配座の多様性がイオン液体の 低融点の原因の一つであると指摘している99. 濱口等は Raman 散乱実験が，これら立体配座を手軽に調べるのに最 適な方法であることを示した $\left.{ }^{12}\right) .\left[\mathrm{C}_{4} \mathrm{mim}\right] \mathrm{X}(\mathrm{X}=\mathrm{Cl}, \mathrm{Br}, \mathrm{I}$, $\mathrm{BF}_{4}, \mathrm{PF}_{6}$ ) に適用し，これらの液体状態では複数の回転異性 体が実際に共存することを示した ${ }^{13)}$ 。これらの研究を端緒 として，種々のイオン液体に扔いて立体配座に焦点を当てた 研究が成されている．Berg 等は Raman 散乱の結果を中心 に，液体打よび結晶の立体配座についての総説を発表してい る ${ }^{14)}$ 。 また，西川グループは Raman 散乱とDSC の同時測 定を行い，相変化時でのイミダゾリウム系カチオンの立体配 座の変化を直接観測している ${ }^{4,15,16)}$.

\section{1 イミダゾリウムカチオンの回転異性体}

代表的なイミダゾリウム系カチオンを 3 つ挙げる． [ $\mathrm{C}_{2}$ $\mathrm{mim}]^{+},\left[i-\mathrm{C}_{3} \mathrm{mim}\right]^{+}$(1-isopropyl-3-methylimidazolium cation), $\left[\mathrm{C}_{4} \mathrm{mim}\right]+$ である. 量子力学計算によると, それぞれ 複数の回転異性体が存在する ${ }^{17,18)}$. しかし, 回転異性体の工 ネルギーダイアグラムや結晶中に存在する実際の立体配座を
調べると，その数は限られる。それぞれ結晶中，あるいはガ ラスや液体中に実際に存在する回転異性体を図示すると,

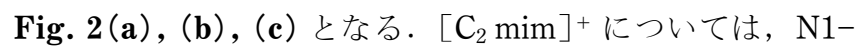
$\mathrm{C1}^{\prime}$ 軸周りの回転異性体で，エチル基がイミダゾリウム環と 同一平面となる構造（Planer）と，エチル基末端の炭素 $\left(\mathrm{C} 2^{\prime}\right)$ がイミダソリウム環に対して立つ構造 (Non-planer) である (Fig. 2(a) ${ }^{19)}$ ・ [i- $\left.\mathrm{C}_{3} \mathrm{mim}\right]+$ では, Sym とAsymを 採ることが多い (Fig. 2(b) ) ${ }^{15)}$. [ $\left.\mathrm{C}_{4} \mathrm{mim}\right]+$ に打いては，ブ チル基の炭素 $\mathrm{C}^{\prime}-\mathrm{C} 2^{\prime}$ を軸とした回転異性体を考えればよい (Fig. 2(c)). C1'-C2'に対して，C2'-C2'軸およびイミダゾ リウム環との結合軸 $\mathrm{C} 1^{\prime}-\mathrm{N} 1$ がゴーシュ型かトランス型かに よって, GT（あるいは $\mathrm{G}^{\prime} \mathrm{T}$ ), TT となる12,13,17,18,20).

注目する軸周りの回転に対するエネルギー変化の一例とし て, [ $\left.\mathrm{C}_{4} \mathrm{mim}\right]+$ の場合を Fig. 3 に示す．このエネルギーダ イアグラムは, カチオンが孤立した状態での密度汎関数法に よる計算結果である。結晶, 液体, ガラスなどの凝集状態で は，近傍のアニオン， カチオンとの相互作用が加わってくる ので現実の系とは異なるが，回転異性体間の相対的な安定性 や，回転する際のエネルギー障壁などについての準定量的な 情報を与えてくれる．これらイミダゾリウム系カチオンに共 通することは，それぞれの安定な回転異性体間のエネルギー

(a)

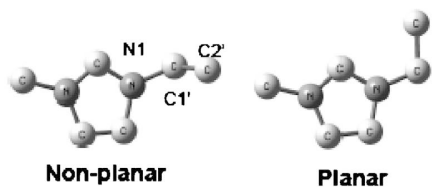

(b)

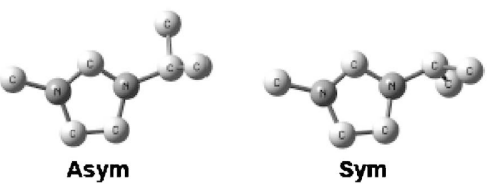

(c)

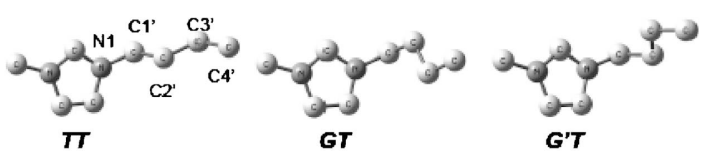

Fig. 2 Stable conformers for (a) $\left[\mathrm{C}_{2} \mathrm{mim}\right]^{+}$, (b) $\left[i\right.$ - $\mathrm{C}_{3}$ $\mathrm{mim}]^{+}$and (c) $\left[\mathrm{C}_{4} \mathrm{mim}\right]^{+}$.

Start: $\mathrm{N} 1-\mathrm{C} 1^{\prime}-\mathrm{C} 2{ }^{\prime}-\mathrm{C} 3^{\prime}=0$

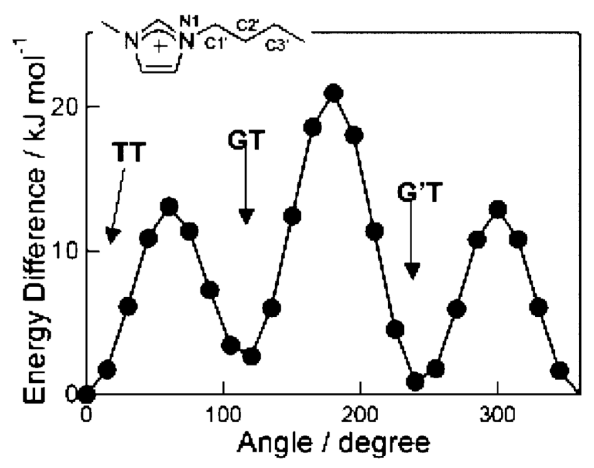

Fig. 3 Potential energy of $\left[\mathrm{C}_{4} \mathrm{mim}\right]^{+}$as a function of torsion angle. Start is defined as $\mathrm{N} 1-\mathrm{C}^{\prime}-\mathrm{C}^{\prime}-\mathrm{C}^{\prime}=0$. 
差は比較的小さいこと, $\mathrm{C} 1^{\prime}-\mathrm{N} 1$ 軸を回転させた場合，底の 浅い安定構造が広い範囲にわたって続くこと年である.

$2.2\left[\mathrm{C}_{2} \mathrm{mim}\right] \mathrm{Br},\left[\mathrm{C}_{3} \mathrm{mim}\right] \mathrm{Br},\left[i-\mathrm{C}_{3} \mathrm{mim}\right] \mathrm{Br},\left[\mathrm{C}_{4}\right.$ $\operatorname{mim}] \mathrm{Br}$ の相挙動

カチオンの立体配座変化に注目するためにアニオンを $\mathrm{Br}-$ に固定した上記 4 種類のイミダゾリウム系イオン液体の DSC 実験結果を紹介する.

$\left[\mathrm{C}_{2} \mathrm{mim}\right] \mathrm{Br}$ を液体状態から冷却しその後昇温させると, 降温過程の $273 \mathrm{~K}$ 付近で結晶化が起こり，昇温過程の 352 $\mathrm{K}$ で融解が起こる ${ }^{5)}$. 過冷却状態が〜 $80 \mathrm{~K}$ 続くことを除い て, 常識的な熱挙動を示している. 単結晶構造解析や Raman 散乱の結果から結晶状態ではカチオンの配座は Nonplanerであり，液体や過冷却液体では Non-planer と Planer が共存することが分かっている ${ }^{19)} .\left[i-\mathrm{C}_{3} \mathrm{mim}\right] \mathrm{Br}$ の DSC トレースをFig. 4 に示す. $\left[\mathrm{C}_{2} \mathrm{mim}\right] \mathrm{Br}$ と同様に, $\left[i-\mathrm{C}_{3}\right.$ $\operatorname{mim}] \mathrm{Br}$ の場合も降温過程で結晶化が起こり, 昇温過程で 融解が起こっている. $20 \mathrm{~K}$ にわたる広い領域の前駆融解現 象（拡大図）が特徵的である. 結晶での $\left[i-\mathrm{C}_{3} \mathrm{mim}\right]^{+}$イオ ンの立体配座はAsym であり，液体では Asym と Sym が混 在する ${ }^{15)}$ ．炭素数 3 の直鎖アルキルの $\left[\mathrm{C}_{3} \mathrm{mim}\right] \mathrm{Br}$ につい ても，ここで簡単に述べておく. $\left[\mathrm{C}_{3} \mathrm{mim}\right] \mathrm{Br}$ は, 数ヶ月に わたって冷蔵庫などに保存すると，たまたま結晶粒がわずか に析出してくることが有るが, 結晶化が難しい. DSCによ る研究報告は今のところ無く, 難結晶性の代表的なイオン液 体と言える。

Fig. $5(\mathbf{a})$ に $\left[\mathrm{C}_{4} \mathrm{mim}\right] \mathrm{Br}$ の DSCトレース 20 を示す。単 結晶をスタート試料とし, $370 \mathrm{~K}$ まで昇温して液体状態にし てから， $1 \mathrm{mK} / \mathrm{s}$ （ $1 \mathrm{~K}$ の温度変化に約 17 分）で $225 \mathrm{~K}$ まで 温度を下げて過冷却状態とし(破線)， $1 \mathrm{mK} / \mathrm{s}$ で昇温させ た (実線). $\left[\mathrm{C}_{4} \mathrm{mim}\right]^{+}$カチオンは, 液体状態抢よび過冷却 液体では TT と GT 配座（おそらく $\mathrm{G}^{\prime} \mathrm{T}$ も）が共存し4,13）, 結晶では GT 配座をとる4,9,13). 図で示すように，降温過程 (破線) では何も起こらないが，昇温過程（実線）の約 250 $\mathrm{K}$ で凝固が起こり, 約 $350 \mathrm{~K}$ で融解が起こる. 降温過程で は結晶化が起こらず，昇温過程で結晶化が起こる現象は，イ オン液体にしばしばみられる現象である22)。すなわち，降 温方向では結晶化に必要な活性化エネルギーが得られないま ま凍りついてしまうが2,5,23), 昇温プロセスでは試料の一部

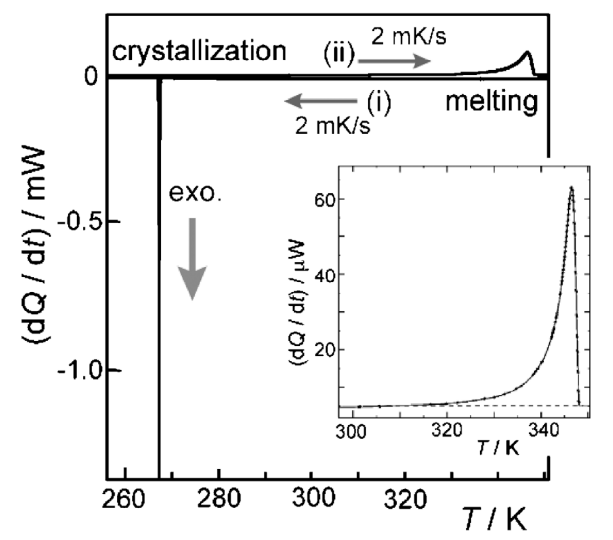

Fig. 4 Overall DSC traces of $\left[i-\mathrm{C}_{3} \mathrm{mim}\right] \mathrm{Br}$.
に不均一な熱ゆらぎが生じ，これがトリガーとなり結晶化が 起こるわけである.ガラス転移は $219 \mathrm{~K}$ 付近であることが 報告されており ${ }^{2,24)}$ ，この凍結状態はガラスでも結晶でもな い. また，Fig. 5(a)に示されるように，10 K 程度にわたる 前駆融解現象が観測されている.

結晶化のシグナルを拡大してみると，発熱ピークは $2 つ$ に割れている20). 結晶化が起こる〜 $250 \mathrm{~K} よ り$ 低温側は過冷 却液体で, ブチル基の立体配座において TTと GT の混合 物である. 結晶化後は GT のみになる.ピークの割れは, GT の立体配座を持っていた部分はすぐ結晶格子を形成でき るが，TTの立体配座のものは一端 GT に立体配座を変えて から結晶化するので，遅れが生じるためである.1イオンだ けの立体配座の変化ではなく, 結晶格子を形成するために, 多くのイオンが協同的に起こる. このような多数の粒子が係 わる構造変化は, $1 \mathrm{mK} / \mathrm{s}$ 程度の温度変化で検知できるよう なスローダイナミックスである。ちなみに，この速度での ピークの分裂は，時間に直すと約 5 分に相当する.

通常では，一端融解が始まると後戻りさせることができな いほど速やかな相転移が起きるが，本試料の前駆融解過程で は温度の上げ下げに伴い可逆的に融解・結晶化がゆっくり進 行する ${ }^{20)}$. 前駆融解過程の昇温途中で降温に切り替える実 験を紹介する. Fig. 5 (b) は, 降温への切り替えが融解の

(a)

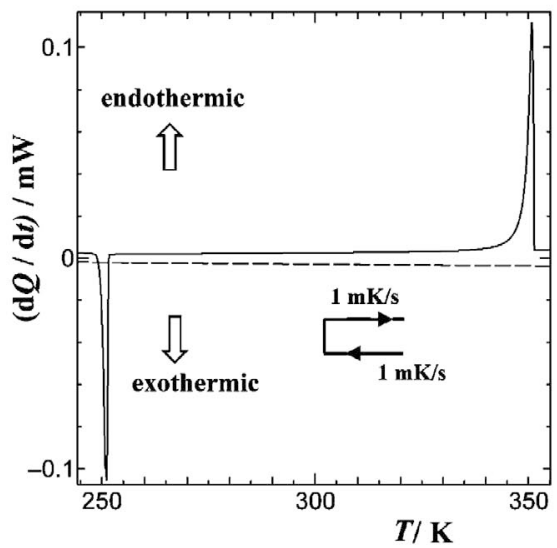

(b)

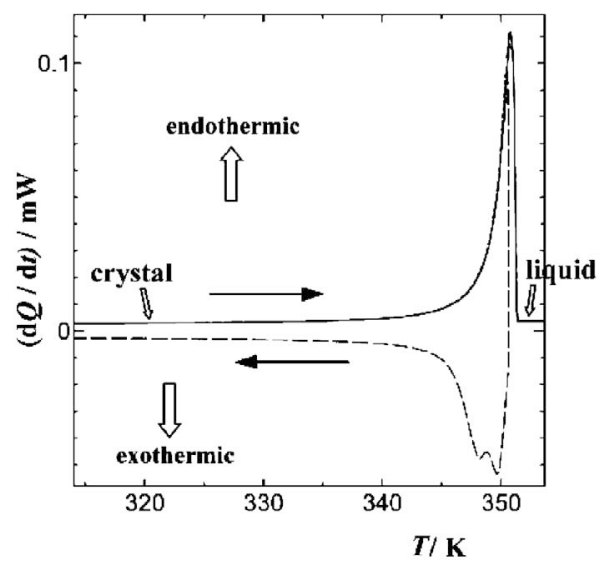

Fig. 5 (a) Overall DSC traces of $\left[\mathrm{C}_{4} \mathrm{mim}\right] \mathrm{Br}$. (b) DSC curves for $\left[\mathrm{C}_{4} \mathrm{mim}\right] \mathrm{Br}$ around the melting point. The broken curve shows the trace where the sample is cooled on the way of the premelting process. The heating and cooling rate are 1 $\mathrm{mK} / \mathrm{s}$. 
ピークにいたる直前の場合のトレース（破線）である.この

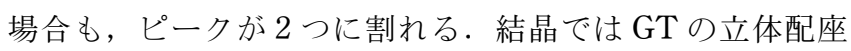
をとり，液体状態では， GT と TTの混合物である。すなわ ち, 前駆融解領域で, 温度上昇とともに butyl 基の一部が TTに変わり，一部分の融解 (local melting) が起こってい る.この状態で, 温度を下げると GT の立体配座のイオンは すぐに結晶格子を形成できるが（高温側の DSC ピーク）, TT に変化したものはGTに変わってから結晶化するので (低温側の DSC ピーク), 時間の遅れが生じる. [ $\left.\mathrm{C}_{4} \mathrm{mim}\right]$ $\mathrm{Br}$ の前駆融解現象は, butyl 基の立体配座の協同的変化と融 解が連動して起こっているためである. Raman 散乱と DSC の同時測定でもこのプロセスが直接観測されている4).

\section{$2.3\left[\mathbf{C}_{4} \mathbf{m i m}\right] \mathbf{P F}_{6}$ の相挙動 ${ }^{16)}$}

$\left[\mathrm{C}_{4} \mathrm{mim}\right] \mathrm{PF}_{6}$ は，代表的なイミダゾリウム系イオン液体 の一つである、にもかかわらず，その相挙動については，多 くの混乱した報告が成されている. 非常に遅速の構造緩和と 複雑な結晶一結晶相変化が存在するためである. 我々による Raman 散乱と熱量の同時測定実験で初めて可能となった $\left[\mathrm{C}_{4} \mathrm{mim}\right] \mathrm{PF}_{6}$ の相挙動についてまとめる.この研究では, 3 つの結晶相の存在が明らかにされ, 低温から出現する順に Crystal $\alpha$, Crystal $\beta$, Crystal $\gamma$ と名付けられている.

液体状態から出発し, $5 \mathrm{mK} / \mathrm{s}$ で $180 \mathrm{~K}$ まで冷却し, 同じ 速度で $313 \mathrm{~K}$ まで昇温した熱量曲線を Fig. 6 に示す. 降温 過程では結晶化は起こらず，190付近にガラス転移が観測さ れる. 昇温過程では, $192 \mathrm{~K}$ 付近で「ガラス $\rightarrow$ 過冷却液体」, $226 \mathrm{~K}$ で「過冷却液体 $\rightarrow$ Crystal $\alpha\rfloor, 250 \mathrm{~K}$ で「Crystal $\alpha \rightarrow$ Crystal $\beta\lrcorner, 276 \mathrm{~K}$ で「Crystal $\beta \rightarrow$ Crystal $\gamma\rfloor$ が起こり, 285 $\mathrm{K}$ で融解する (それぞれのピーク值で温度を指定). Crystal $\gamma$ の存在は本実験で初めて報告された. 非常に小さな吸熱 ピークであること, 融解のピークに近いこと, Crystal $\gamma へ$ の変化が非常にゆっくりした变化であるため, 通常の市販の DSC 装置の掃引速度では検知できなかったためである.

Crystal $\alpha, \beta, \gamma$ 相の Raman スペクトルと密度汎関数法で 計算した $\left[\mathrm{C}_{4} \mathrm{mim}\right]^{+}$の GT, TT, G'T の振動バンドを比べ ると, Crystal $\alpha, \beta, \gamma$ 相の $\left[\mathrm{C}_{4} \mathrm{mim}\right]+$ がそれぞれ GT, TT, $\mathrm{G}^{\prime} \mathrm{T}$ を採っていることがわかった。 すなわち, これらの結 晶一結晶相変化は, $\left[\mathrm{C}_{4} \mathrm{mim}\right]+$ のブチル基の立体配座の変化 により引き起こされている.

報告されている結晶構造解析では, $\left[\mathrm{C}_{4} \mathrm{mim}\right]^{+}$は $\mathrm{G}^{\prime} \mathrm{T}$

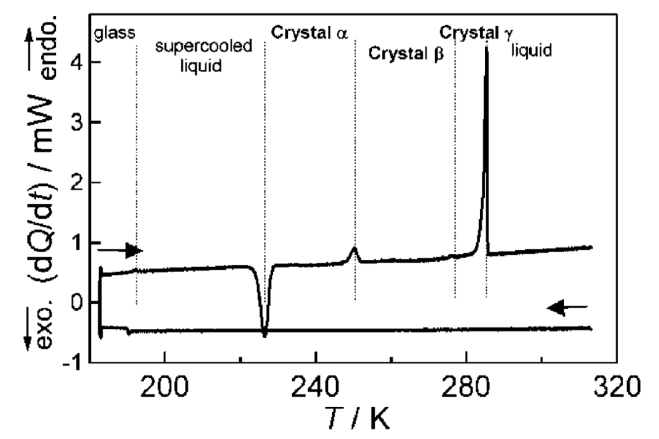

Fig. 6 Calorimetric curves of $\left[\mathrm{C}_{4} \mathrm{mim}\right] \mathrm{PF}_{6}$ at a scanning rate of $5 \mathrm{mK} / \mathrm{s}$ for the whole temperature range.
$($ Crystal $\gamma)$ である ${ }^{25)}$. 液体, 過冷却液体, ガラスでは GT, $\mathrm{TT}, \mathrm{G}^{\prime} \mathrm{T}$ が共存する. 前駆融解領域から融解を経て液体に 至る過程の熱量分析と Raman 散乱の同時測定より, スター 卜時点では Crystal $\gamma$ の ${ }^{\prime} \mathrm{T}$ であり, 前駆融解が進むにつれ GT, TT 配座の成分がわずかずつ生じ, 融解ピーク (285 K) を超えると, 急激に配座の変化が進行することが明らかにな った ${ }^{16)}$. なた， ${ }^{13} \mathrm{C}-\mathrm{NMR}$ 測定より，イミダゾリウム環およ び側鎖のブチル基の各炭素の運動性の違いが, 複雑な相挙動 の一因であることが明らかになった ${ }^{8)}$.

\section{3. イオン液体に特有な新奇な相挙動}

\section{1 融解・結晶化のモデル}

これまでの結果を総合して, 我々は, Fig. 7 に示すよう なイオン液体の融解・結晶化のモデルを立てている．結晶状 態では，イオンは規則正しく並んでいる (Fig. 7(a)). 昇温 過程で, 結晶中に, 構成イオンの立体配座の変化を伴いなが ら部分的な融解 (local melting) が起こる (Fig. 7(b)). こ れが前駆融解過程のスタートに相当する. local meltingの 起こりやすい領域は, 結晶の表面・界面や結晶欠陥などであ る. 温度の上昇と共に融けた領域は広がり, 液体を連ねた領 域が端から端をで連なる状態 (Fig. 7(c)) を経て, 結晶領 域が端から端まで連なる状態 (Fig. 7(d)) となる. Fig. 7(d) の状態が，DSCトレースのピークと思われる。ここを境に して，3.4で述べるように, 可逆的に結晶化が起こるか否か が決をる，さらに，温度を上げていくと液体となるが，この 状態でも結晶の粒は残っていると思われる (Fig. 7(e)). さ らに温度を上げていくと完全に液体となる（Fig. 7(f)). 以 上は, 融解過程のモデルであるが, 結晶化ではこの逆のプロ セスが進行する.

もちろん, 上記のようなプロセスはほとんどの物質で起こ っていると思われが, 高分子試料などを除いて, 変化が高速 のため実験的に捉えられることはほとんど無い.イオン液体 の場合, 変化のプロセスが非常に緩慢なため, これらのプロ セスが以下のような現象として実験的に捉えることが出来る.

\section{2 リズム的な融解・凝固過程 26$)$}

$\left[\mathrm{C}_{4} \mathrm{mim}\right] \mathrm{Br}$ の前駆融解現象で見出された興味深い現象を 紹介する. Fig. 5(a)の融点近傍を, 非常にゆっくりした昇

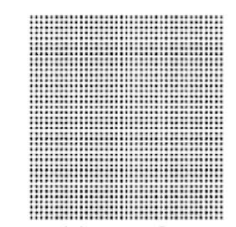

(a) crystal

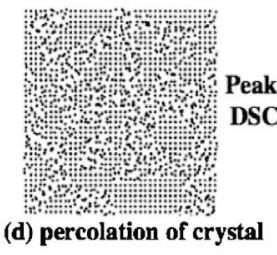

tion of crystal

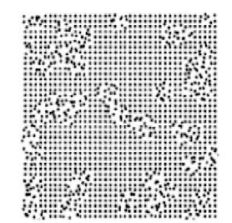

(c) percolation of liquid (b) local melting

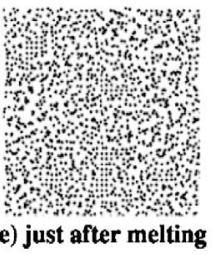

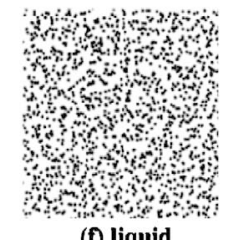

(f) liquid
Fig. 7 A schematic model for melting and crystallization. 
温速度 $0.02 \mathrm{mK} / \mathrm{s}$ （1 K 温度上昇させるのに 14 時間）での実 験結果をFig. 8(a)に示す. Fig. 8(a)に示すように, 細かい 熱の出入りの多い鋸歯状 DSC トレースとなった.しかし, これはノイズではない. 熱の出入りの最も激しい部分（前駆 融解領域の中間部分, Fig. 8(a)の(3) 付近) を拡大したのが Fig. 8(b)である. 60〜 $80 \mathrm{nW}$ の熱の出入りを繰り返してい ることがわかる。これに対して, 液体として定常状態になっ たと思われる領域 (Fig. 8(a)の (5) 付近) を拡大してみると, 鋸歯状のシグナルは $\pm 3 \mathrm{nW}$ である.これは, 用いた超高感 度装置のノイズレベルに対応している. 領域 (3) 付近の鋸歯 状のシグナルは, 装置由来のノイズより $20 ３ 0$ 倍程度大き い.ちなみに, 通常の市販装置のベースライン安定性は, $\pm 3 \sim 5 \mu \mathrm{W}$ で 3 桁程度落ちる. 通常の DSC 装置では領域 (3)のような現象を検知できない.

Fig. 8(b)で示される熱の出入りは, 以下のように解釈さ れる. すなわち, 試料中の一部分に熱的に不均一な領域がで き, local melting が起こる. 非常にゆっくりした昇温速度 なので, 外部からの熱の供給量は少ない. 融解は吸熱現象で あり, 周辺から熱を奪う。熱を奪いすぎたことにより, 融解 しかけた一部が冷却し結晶化が起こる. 結晶化により, また 熱が発生し融解が進行する. この融解・凝固現象をリズム的 に繰り返しながら全体として融けていく。すなわち, 微少領 域の一つの相変化に伴う熱の出入りが, 次の相変化のトリ

(a)

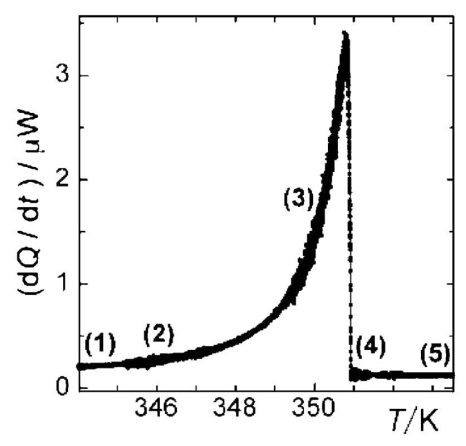

(b)

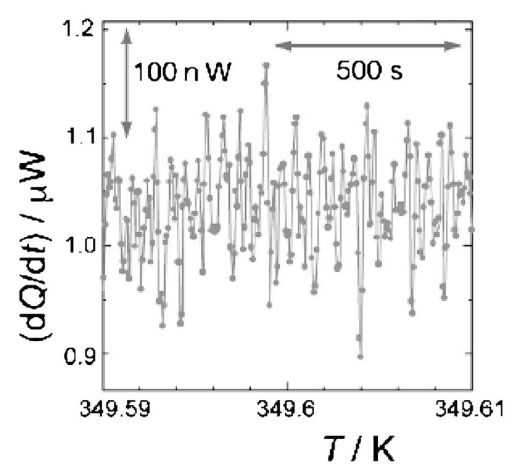

Fig. 8 (a) DSC trace of $\left[\mathrm{C}_{4} \mathrm{mim}\right] \mathrm{Br}$ near the melting point. The heating rate is $0.02 \mathrm{mK} / \mathrm{s}$. Five divisions are selected and numbered as (1)-(5). (b) Expanded figure of the division (3). Dots in (b) refer to the measuring points of every 4 s.
ガーとなり, 融解・凝固の相変化が繰り返されていく. Fig. 8(b)の細かい熱の出入りは，この繰り返しを観ているもの である. 酸化還元反応が行きつ戻りつする化学反応として, Zhabotinsky 反応が有名である. イオン液体の融解過程で見 出された本現象は相变化に括けるリズム的現象であり, 西川 等はこれを『リズム的融解・凝固過程』と名付けた。このよ うな現象が見出されたのは, $\left[\mathrm{C}_{4} \mathrm{mim}\right] \mathrm{Br}$ の融解過程が数十 秒オーダーのスローダイナミックスに支配されて抢り, 使用 した DSC 装置の緩和時間より十分長いためと言える.

熱の出入りの量から見積もると, $1.8 \times 10^{13}$ 個程度のイオ ンペアが融解・結晶化を繰り返していることになる．この領 域を相転移のドメイン（Fig. 7(b)の融けた領域）と表現す ると, ドメインが結晶化あるいは融解するタイムスケールは 12〜20秒である.

また, Fig. 8(a)の領域 (4)は融解直後である.この領域で もDSCトレースは安定せず，リズム的な発熱・吸熱を繰り 返している，結晶格子は融解しているが，結晶的な粒（ドメ イン）が存在し, これが融解・結晶化を繰り返していると思 われる (Fig. 7(e)に対応).このドメインの中のイオンペア の数は, $2 \times 10^{12}$ 個程度で, (3)の領域に比べ, 1 桁ほど少な い。 また, 前駆融解現象が始をる領域 (2)においては, リズ ム的融解・結晶化をスタートさせるドメインに，(4)と同じ $2 \times 10^{12}$ 個程度のイオンペアが含まれている.

\section{3 間歇的結晶化 ${ }^{21,27)}$}

$\left[i-\mathrm{C}_{3} \mathrm{mim}\right] \mathrm{Br}$ を試料として, 前駆融解領域の融解ピーク 直前で $2 \mathrm{mK} / \mathrm{s}$ の昇温から $0.05 \mathrm{mK} / \mathrm{s}$ の降温に切り替えた 実験結果を示す. Fig. 9 (a) は前駆融解領域（Fig. 4 の融解 部分）の全体, Fig. 9(b)は降温過程の $334 \mathrm{~K}$ 付近の拡大図 である. 昇温過程と降温過程で, 温度変化の速度が異なるの で, 昇温（降温）速度 $\beta$ で規格化している. 鋸歯状のピー クが観測され，これらすべて発熱ピークであることにご注目 いただきたい，鋸歯状のこの発熱ピークは，一つ一つのドメ インが間歇的に結晶化している現象であり，我々はこれを 『間歇的結晶化』と名付けた，昇温から降温への切り替えで, local melting していたうちでAsymの配座を持っていた部 分は速やかに結晶化する。しかし, Symに構造变化し Asym と混ざり合った部分は, 結晶化しにくく取り残される (Fig. 7(b)の模式図に対応). local melting したドメインが あちこちに取り残され，温度の降下とともに，これらのドメ インが個々に結晶化する現象と説明することができる.

間歇的結晶化を起こしているドメインに含まれるイオンペ アの数は, 本実験の条件で $3 \times 10^{14}$ 個程度である。 また, 一 つのドメインが結晶化するのに要する時間は 100 秒程度であ る.このような現象が観測されたのは本試料が初めてである.

\subsection{DSC のピークを越えると21)}

やはり，試料は $\left[i-\mathrm{C}_{3} \mathrm{mim}\right] \mathrm{Br}$ である. DSCトレース （Fig. 4）のピークをわずかに越えてはいるが，まだ液体状 態のベースラインに至っていない点を昇温-降温の切り替え 点として, $0.05 \mathrm{mK} / \mathrm{s}$ での降温実験の結果を Fig. 10 に示 す. 切り替え温度が DSCのピークを越えない場合は, 前述 したように local melting した部分は可逆的に結晶に戻る. しかし，本実験のようにピークを越えてから戻すと，もはや 
(a)

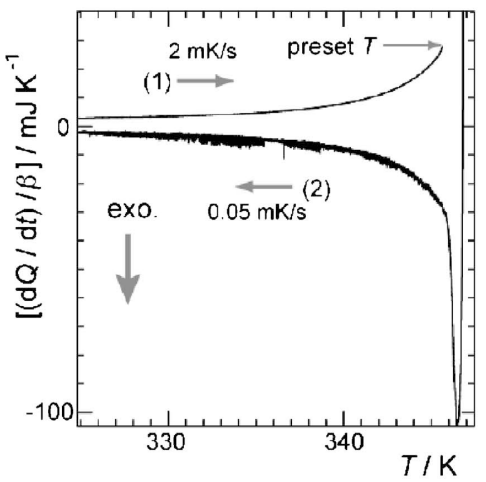

(b)

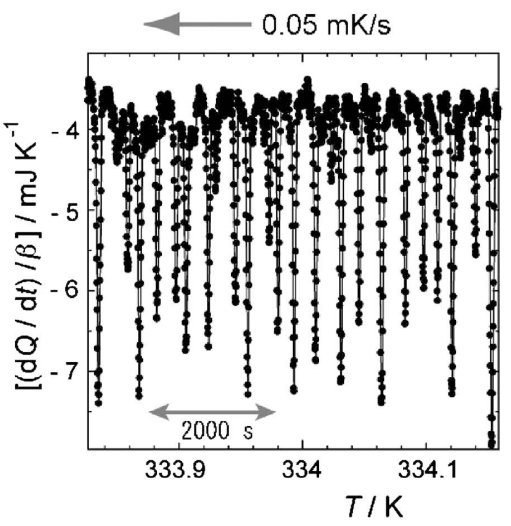

Fig. 9 The DSC traces for $\left[i-\mathrm{C}_{3} \mathrm{mim}\right] \mathrm{Br}$ around the melting point. The curve shows the trace wherein the sample was cooled down from $346.0 \mathrm{~K}$. (a) Full scale drawing and (b) magnified drawing around $334 \mathrm{~K}$ in the cooling run.

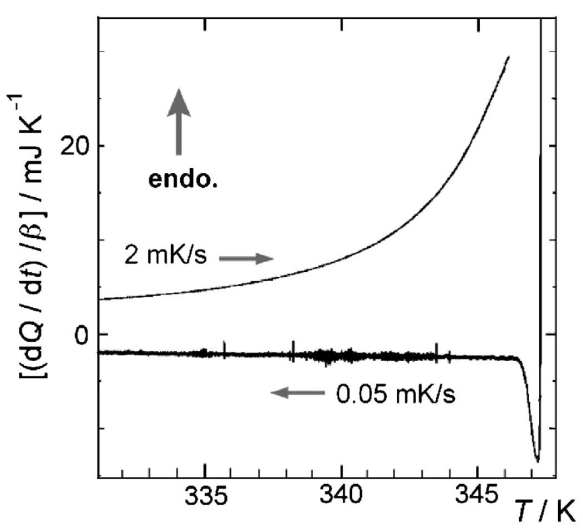

Fig. 10 The DSC traces for $\left[i-\mathrm{C}_{3} \mathrm{mim}\right] \mathrm{Br}$ around the melting point. The sample was cooled down with a cooling rate of $0.05 \mathrm{mK} / \mathrm{s}$ from the temperature of $0.2 \mathrm{~K}$ higher than the peak-top of the melting trace.

結晶化しない。この場合, 過冷却液体となり，降温過程の $270 \mathrm{~K}$ 付近 (Fig. 4 参照) で初めて結晶化が起こる.すなわ ち, DSCの融解のピーク付近が可逆的に結晶化・融解が起 こるかの境目である。構造的には, 結晶部分のパーコレーシ ヨンが寸断される温度（Fig. 7 (d) と（e)の間に対応）と考え られる.
しかし，スムースに過冷却液体になるのではなく， $\left[\mathrm{C}_{4}\right.$ $\mathrm{mim}] \mathrm{Br}$ について3.2で述べたように, リズム的な融解・凝 固現象が観測される.やはり, 結晶部分の融解による吸熱が トリガーとなり, 融解したドメインあるいはその周辺が結晶 化し, 今度はその際放出される熱でまた融けるという現象が 繰り返されて, 過冷却液体に至る。装置からのノイズ幅 \pm 3 $\mathrm{nW}$ との比較から明らかなように, 鋸歯状の熱の出入りはこ れよりはるかに大きく, 実際に熱が出入りしていることを示 している.

\section{4. おわりに}

相挙動におけるイオン液体に特徵的な現象（安定な過冷却 液体状態, 前駆融解現象, 長時間を要する相転移や構造緩 和）や新奇な現象（可逆的凝固・融解, リズム的な融解・凝 固, 間歇的結晶化）を紹介した。これらはすべて, 構成イオ ンの立体配座が相変化と連動して起こっているためと考えら れる. 相変化するのには, 非常に多くのイオンペアが協同的 に構造変化をし，大きな活性化エネルギーと時間を要する. このため, スローダイナミックス2)で起こる現象として捉え ることが出来た.

これらの現象の見かけはそれぞれ異なるが，すべて上記し た立体配座の多㥞性と相変化との連動にその原因が㡩せられ るであろう。これらの現象が観測されるか否か，あるいはど の現象が観測されるかは, 相変化のエンタルピー, 活性化エ ネルギー, 立体配座間のエネルギー差, 外部からの熱流量, 熱伝導率, 異なる立体配座の存在比とその混ざり具合等に依 存していると言える.

イオン液体に抢いて，構成イオンが複数の立体配座を持つ ことが一般的である，立体配座の多様性が，(a) 結晶多系の 存在，(b) 低融点，(c) 結晶化しにくいこと, (d) 物性に扔い て熱履歴を伴うこと等の一因となっている.これらは, イオ ン液体の本質と深く関わっていることであり, 少々大まかな 言い方が許されるとするなら, 構成イオンの立体配座の多様 性が原因であると結論される.

\section{〔文献〕}

1) J. M. S. S. Esperança, J. N. C. Lopes, M. Tariq, L. M. N. B. F. Santos, J. W. Magee and L. P. N. Rebelo: J. Chem. Eng. Data, 55 (2010) 3.

2) M. Imanari, K. Fujii, T. Endo, H. Seki, K. Tozaki and K. Nishikawa: J. Phys. Chem. B, 116 (2012) 3991.

3) S. Wang, K. Tozaki, H. Hayashi and H. Inaba: J. Therm. Anal. Calorim., 79 (2005) 605.

4) T. Endo, K. Tozaki, T. Masaki and K. Nishikawa: Jpn. J. Appl. Phys., 47 (2008) 1775.

5) M. Imanari, K. Uchida, K. Miyano, H. Seki and K. Nishikawa: Phys. Chem. Chem. Phys., 12 (2010) 2959.

6) M. Imanari, H. Seki and K. Nishikawa: Gendai-Kagaku, No. 474 (2010) 30.

7) T. Endo, S. Widgeon, P. Yu, S. Sen and K. Nishikawa: Phys. Rev. B, 85 (2012) 054307.

8) T. Endo, H. Murata, M. Imanari, N. Mizushima, H. Seki and K. Nishikawa: J. Phys. Chem. B, 116 (2012) 3780.

9) J. D. Holbrey, W. M. Reichert, M. Nieuwenhuyzen, S. Johnson, K. R. Seddon and R. D. Rogers: Chem. Commun., 14 (2003) 1636.

10) S. Hayashi, R. Ozawa and H. Hamaguchi: Chem. Lett., 32 
(2003) 498.

11) S. Saha, S. Hayashi, A. Kobayashi and H. Hamaguchi: Chem. Lett., 32 (2003) 740.

12) R. Ozawa, S. Hayashi, S. Saha, A. Kobayashi and H. Hamaguchi: Chem. Lett., 32 (2003) 948.

13) H. Hamaguchi and R. Ozawa: Adv. Chem. Phys., 131 (2005) 85.

14) R. W. Berg: Monatsh. Chem., 138 (2007) 1045, and references cited therein.

15) T. Endo and K. Nishikawa: J. Phys. Chem. A, 112 (2008) 7543.

16) T. Endo, T. Kato, K. Tozaki and K. Nishikawa: J. Phys. Chem. B, 114 (2010) 407.

17) E. A. Turner, C. C. Pye and R. D. Singer: J. Phys. Chem. A, 107 (2003) 2277.

18) S. Tsuzuki, A. A. Ayusawa and K. Nishikawa: J. Phys. Chem. B, 112 (2008) 7739.

19) Y. Umebayashi, T. Fujimori, T. Sukizaki, M. Asada, K. Fujii, R. Kanzaki and S. Ishiguro: J. Phys. Chem. A, 109 (2005) 8976.
20) K. Nishikawa, S. Wang, H. Katayanagi, S. Hayashi, H. Hamaguchi, Y. Koga and K. Tozaki: J. Phys. Chem B, 111 (2007) 4894.

21) K. Nishikawa, S. Wang, T. Endo and K. Tozaki: Bull. Chem. Soc. Jpn., 82 (2009) 806.

22) C. P. Fredlake, J. M. Crosthwaite, D. G. Hert, S. N. V. K. Aki and J. F. Brennecke: J. Chem. Eng. Data, 49 (2004) 954.

23) M. Imanari, M. Nakakoshi, H. Seki and K. Nishikawa: Chem. Phys. Lett., 459 (2008) 89.

24) Y. U. Paulechka, G. J. Kabo, A. V. Blokhin, A. S. Shaplov, E. I. Lozinskaya and Y. S. Vygodskii: J. Chem. Thermodyn., 39 (2007) 158.

25) A. R. Choudhury, N. Winterton, A. Steiner, A. I. Cooper and K. A. Johnson: J. Am. Chem. Soc., 127 (2005) 16792.

26) K. Nishikawa, S. Wang and K. Tozaki: Chem. Phys. Lett., 458 (2008) 88.

27) K. Nishikawa and K. Tozaki: Chem. Phys. Lett., 463 (2008) 369. 